\title{
Retracted Article: Decompressive craniectomy without durotomy for traumatic coma and uncontrollable intracranial hypertension
}

Daniel James Miller ${ }^{1 *}$ and Darlene Angela Lobel ${ }^{2}$

The Publisher has retracted this article [1] because it appears that the authors did not obtain the necessary consent to publish their case details from the patients described. The article is no longer available online in order to protect the patients' privacy. Darlene Lobel has agreed to retraction, Daniel Miller could not be reached by the journal for comment on the retraction.

\footnotetext{
Author details

'Division of Neurosurgery, Department of Surgery, Associate Clinical Professor of Neurosurgery, University of California, San Francisco-Fresno, 2335 East Kashian Lane, Suite 301, Fresno, California 93701, USA. ${ }^{2}$ Center for Neurological Restoration, Department of Neurosurgery, Neurologic Institute, Cleveland Clinic, 9500 Euclid Avenue, S31, Cleveland, Ohio, USA.
}

Received: 15 March 2013 Accepted: 4 October 2013

Published: 29 October 2013

\section{Reference}

1. Miller DJ, Lobel DA: Decompressive craniectomy without durotomy for traumatic coma and uncontrollable intracranial hypertension. Journal of Trauma Management \& Outcomes 2013, 7:8.

\footnotetext{
* Correspondence: djmmd@yahoo.com

'Division of Neurosurgery, Department of Surgery, Associate Clinical Professor of Neurosurgery, University of California, San Francisco-Fresno, 2335 East Kashian Lane, Suite 301, Fresno, California 93701, USA

Full list of author information is available at the end of the article
}

\section{Submit your next manuscript to BioMed Central} and take full advantage of:

- Convenient online submission

- Thorough peer review

- No space constraints or color figure charges

- Immediate publication on acceptance

- Inclusion in PubMed, CAS, Scopus and Google Scholar

- Research which is freely available for redistribution 